\title{
Strategic tool to estimate the consumption patterns of non-residents spectators at sporting events (Liga NOS): Adaptation to Portuguese reality
}

\author{
Gonçalo Quintal ${ }^{\dagger}$ \\ Faculdade de Economia da Universidade do Porto \\ Gustavo Paipe $\mathbf{\Omega}^{\mathrm{T}}$ \\ Faculdade de Desporto da Universidade do Porto \\ José Luis Felipe ${ }^{\mathrm{x}}$ \\ Universidad Europea de Madrid \\ Maria José Carvalho* \\ Faculdade de Desporto da Universidade do Porto
}

\begin{abstract}
The purpose of this study was to adapt the questionnaire of Preuss, Seguin and O'Reilly (2007) to Portuguese reality to analyse the phenomenon of consumption patterns of non-residents spectators at sporting events. For this, an exploratory study was conducted to check its psychometric properties when applied to Portuguese reality. For the sample, 58 non-resident spectators were randomly selected in the match between Futebol Clube Paços de Ferreira and Sporting Clube de Portugal of 19th round of Liga NOS in the city of Paços de Ferreira. Data analysis was based on descriptive statistics and Cronbach's alpha reliability test. The results suggest acceptable values for internal consistency and reliability. As main conclusions, the adapted version can be used to analyse the profile and consumption patterns of non-residents spectators, which will help to define marketing strategies more effective and efficient for clubs and host cities, thus contributing to improving offer and more quality in the services provided for spectators of such events.
\end{abstract}

Keywords: Marketing; Consumer; Events; Economic Impact; Questionnaire.

Received in 05/09/2016; revised in 06/08/2016; accepted in 07/06/2016; divulgued in 11/21/2016

*Author for correspondence:

$\dagger$. Licenciado em economia Instituition: Faculdade de Economia da Universidade do Porto Address: Rua Henrique Sousa Reis, 127 Habitação 4.1 4200-008 Porto E-mail: goncalonquintal.9@gmail.com
${ }^{\dagger}$. Mestre em gestão desportiva Instituition: Faculdade de Desporto da Universidade do Porto

Address: Rua Dr. Plácido Costa, 91 Porto, Portugal

E-mail: gustavaopaipe@gmail.com
${ }^{\dagger}$. José Luis Felipe Instituition: Universidad Europea de Madrid

Address: Calle Tajo, s/n Villaviciosa de Odón Madrid, Espanha E-mail: joseluis.felipe@ universidadeuropea.es
* Doutora em ciências do desporto Instituition: Faculdade de Desporto da Universidade do Porto Rua Dr. Plácido Costa, 91 Porto, Portugal E-mail: mjc@fade.up.pt

Note from the Editor: The article was accepted by Bruno Felix. 


\section{INTRODUCTION}

porting events are leisure opportunities. Thereby, during these events the spectators are released from the daily stresses and experience a healthy excitement to get involved in the story that is told through the show. For this reason, sporting events have been studied over the past decades, because they generate a lot of positive and negative impacts (SANZ et al., 2012). The major studies (CROMPTON, 1995; GRATTON et al., 2000; PREUSS, 2005; SIEGFRIED; ZIMBALIST, 2006; AGHA, 2013) show the economic importance of events through analysis of the economic impact in host cities.

These studies are usually conducted in mega sporting events (PREUSS, 2004), such as the soccer world championships or the Olympic Games and that are often overestimated, to legitimate positions of stakeholders (MONDELLO, 2006). Nevertheless, there are few studies that analyse the economic impact on small-scale sporting events (GIBSON et al., 2012) because there is great difficulty to analyse the economic impact of these small sporting events (BARAJAS et al., 2015).

Spectators have a significant role in sporting events, therefore, the behaviour analysis of them has taken a growing role in academic research (TRAIL et al., 2003; ALLAN et al., 2007; AMY, 2007; LERA-LÓPEZ et al., 2012). Therefore, knowing the factors that influence people's decisions to attend the games is crucial for sports organizations in order to involve and attract more viewers to this phenomenon. This, increases the notoriety of teams and clubs, as well as income ticket and associates, such as grants from the bars or merchandising in the official shops, producing direct and indirect benefits to sport organizations (BISCAIA et al., 2010).

The analysis of consumption patterns of a population is fundamental to know and target the people who participate in sporting events, including non-resident spectators because they are those who bring "new money" for the city (CROMPTON et al., 2001; GRATTON et al., 2005; CROMPTON, 2006).

However, there is a lack in the literature regarding the analysis of consumption patterns of spectators of small sporting events, in particular those carried out by the professional football clubs of the major league in Portugal (Liga NOS). Taking into account this situation, the aim of this study was to adapt the questionnaire of Preuss, Seguin and O'Reilly (2007) to the Portuguese reality to analyse the profile and the consumption patterns of non-resident spectators in Liga NOS.

\section{LITERATURE REVIEW}

The sports industry growth has attracted the focus of research of several economists. For this reason, sports economy has become widely recognized as a sub-discipline of the economy, with an active research agenda (SANTOS; GARCIA, 2011). Sport has acquired a great importance in many facets of social and economic life, such as economic urban regeneration and wealth creation agent 
for cities and regions, through the "sports tourism" and in terms of social engineering, to promote inclusion, self-fulfilment and the development of communities (HASSAN; CONNOR, 2009).

Many economic agents believe that sporting events and local professional teams generate substantial levels of economic development and increase the enhancement of the image of a city or region. The idea that sporting events promote economic development is rooted in intuition that the consumption of hundreds of thousands or even millions of people who attend the games generate many economic benefits (SANDY, 2004). In particular, soccer support this idea of economic development (GÓMEZ-BANTEL, 2015).

An event is, when properly framed, an exceptional catalyst for development in any context. In sport, this capability has been a growing importance, depending on how the post-modern society values entertainment, fun and pleasure (SARMENTO et al., 2011). In this regard, Getz (2008) argues that there are three types of events that attract more attention of researchers and practitioners are: business, sports and festivals. In this sense, Barreau (2001) defines sporting event as a spectacle, a product and a company. A spectacle, because the organization exists around a unity of action, time and space; a product, because the organization of the sporting event is part of a marketing approach and capital management and; a company, because it keeps a feature common to any company, i.e. the risk.

Gratton, Dobson and Shibli, (2000) claim four types of events: A, B, C and D. Type A are the mega-events, such as Olympic Games or World Championships of different modalities; The Type B includes sports events held annually, such as the final Cup of different modalities in each country; Type C, are irregular events of national or international level, such as National Swimming Championships. Finally, type D corresponds to a national regular basis event like a game or a championship tournament.

Wilson (2006) argues that there is another dimension, type E, which corresponds to the smaller events where athletes may be more numerous than the spectators. While $\mathrm{C}$ and $\mathrm{D}$ type events can generate a more limited economic activity, its results and net benefit to the local community may actually be more positive when compared to the type of events A and B (AGHA, 2015).

The economic impact of sporting events is measured by the input of the 'new money' in the city or region, which can be directly attributed to the event. This 'new money' is defined by Crompton (2006) as the consumption generated by the sports event that would not have occurred in the region without the event had been held. According to Gratton (2005), the 'new money' can be estimated by the consumption generated by the spectators. In order to achieve the measuring of the economic impact, these agents should assign 'new money' to one of the following intakes: ticketing, accommodation, food and drinks, local transportation, souvenirs and shopping.

The use of consumption made by residents' spectators during sporting events for estimation of the impact analysis has generated much discussion in two schools of thought. Researchers such as Crompton (1995) and Gratton, Shibli and Coleman (2006) argue that consumption should not be 
included as 'new money' generated by the event, because it represents money that already exists in the city. On the other hand, researchers such as Preuss, Seguin and O'Reilly (2007) consider that consumption of residents should be take into account, because, without the event, residents could travel and spend their money outside the city. For this study, we opted to consider only the consumption of non-residents spectators of the event.

Although the economic impact of sporting events have been widely studied (PREUSS, 2004; WILSON, 2006much of the research in the UK has focused on the economic impacts of sport events such as the First Cornhill Test Match; England vs. Australia (1997; GIBSON et al., 2005; GRATTON et al., 2006; BAADE et al., 2008; HUANG et al., 2014; LAMLA et al., 2014), analysis of the expenditure made by the spectators in the events has been neglected (MAK, 2004).

Sporting events, provide a great opportunity for development of marketing strategies for the clubs and host cities (GOLDBLATT, 2000) because the collection and dissemination of qualified information on the spending of spectators will help event organizers to demonstrate the economic benefits they produce in the communities, as well as improving the understanding of the pattern of consumption of the spectators.

For Allen (2007) a successful marketing strategy comes from a better understanding of consumers and their needs. According to Kotler (2012), the marketing begins with the needs and human desires. These two concepts improve the marketing decision-making, because from them is formed the marketing strategy that the company will determine what will be its market. Hall (1992) explains that marketing is part of event management that allows to create contact with consumers, attending the event, capturing their needs and motivations, developing products that replicate those needs in a communication plan that expresses the purpose of the event.

Sport marketing receives a high degree of attention due the involvement of consumers. People are motivated to be involved in sport for a variety of reasons including economic, political, aesthetic, social, community and collective (GUTTMAN, 1986). Sports marketers need to identify the most prominent features that attract spectators, participants and views (RATTEN; RATTEN, 2011), because it is important to understand how consumers identify with sport in order to make it more effectively (RATTEN, 2016).

The creation of profiles that include information on expenditures, as well as socio-demographic characteristics and travel behaviour of different types of attenders, provides organizers with valuable information that can be used to identify products and services that complement the wishes of spectators at sporting events (HINCH; HIGHAM, 2001).

In this sense, further research on the spectators consumption patterns is important for acquisition of data required for marketing segmentation (WILTON, 2006). According to Churchill (2005) market segmentation consists of dividing it into groups of potential buyers who have similar needs and desires, perceptions of values or buying behaviours. 
Wilton (2006) also states that the identification of the characteristics and specific target markets behaviour is vital for development of effective and efficient marketing strategies for clubs and the cities hosting the events. For this reason, sports market segmentation has increased in popularity as strategy for organizations to target appropriate consumers (RATTEN, 2016).

However, the estimation of expenditure incurred by sports spectators can be a challenging task, as there are various factors that allow to estimate the expenses of spectators, such as the number of spectators and their daily consumption; the types of spectators and types of events; the duration of the trip and the expenses at the event (MULES; DWYER, 2005). This estimation is usually done by conducting questionnaires during events (MULES; DWYER, 2005). For this reason, this tool is appropriate in the context of planning the marketing strategy because it will gather data about the spectators and will allow to understanding and targeting Portuguese market.

There is growing consensus among sports marketing researchers around the view that improved marketing intelligence and planning should be the goal of sports organizations. This means that, sports marketers should engage in activities that drive positive planning approaches to future business activities (RATTEN, 2016).

Therefore, the aim of this study was to adapt the questionnaire of Preuss, Seguin and O'Reilly (2007) to the Portuguese reality to analyse the profile and the consumption patterns of non-resident spectators in Liga NOS.

\section{METHOD}

With a $95 \%$ significance level and the error margin set at $13 \%$, the sample was randomly selected, and consisted in 58 non-resident spectators in the match between Futebol Clube Paços de Ferreira (FCPF) and Sporting Clube de Portugal of $19^{\text {th }}$ round of Liga NOS in the city of Paços de Ferreira.

The questionnaire was already translated into Portuguese because had already been applied at FIFA World Cup 2014 in Brazil, and was only necessary to adapt to the current language used in Portugal. After this adjustment, we performed a pre-test to non-residents spectators at matches at the FCPF stadium.

In Table 1, are presented the 20 questions in the questionnaire distributed by the following 4 dimensions: (i) Spectator profile analysis (PE); (ii) Spectator consumption patterns (SC); (iii) Spectator behaviour (CE); and (iv) Spectator opinion of local conditions (OE).

The questions were mostly with closed response options. However, the question 8, 13, 19 and 20 , the possible answers were based on ordinal scale and polychotomous. In question 8 , the Likert five-points scale were used and the possible answers were: Never (1) Rarely (2) Sometimes (3) Often (4) and Always (5). In question 13, the same scale was used but with different options of the 
Table 1. Dimensions and questions

\begin{tabular}{|c|c|c|c|}
\hline \multirow[t]{4}{*}{ Dimension } & \multirow[t]{4}{*}{ N. ${ }^{\circ}$ of Items } & \multicolumn{2}{|c|}{ Item } \\
\hline & & \multicolumn{2}{|c|}{ Company for the game } \\
\hline & & \multicolumn{2}{|c|}{ Company to visit the city but do not attend to the game } \\
\hline & & & own \\
\hline (i) Spectator profile & 7 & $\begin{array}{l}\text { Please consider the following } \\
\text { statements: }\end{array}$ & $\begin{array}{l}\text { I practice/I practiced football; I } \\
\text { practice/I practiced other sports; } \\
\text { I follow football games from } \\
\text { the leagues below Liga NOS; I } \\
\text { follow football games in interna- } \\
\text { tional leagues }\end{array}$ \\
\hline
\end{tabular}

Age and Sex

Level of education

Monthly income

Ticket purchase

$\begin{array}{ll}\begin{array}{l}\text { (ii) Spectator consumption } \\ \text { patterns }\end{array} & \begin{array}{c}\text { Food and drink; Shopping; } \\ \text { Accommodation; Travel costs; } \\ \text { Tickets for the game; Others }\end{array}\end{array}$

Visit intention

Length of stay in the city

Stay in town

Please answer the following questions:

Intend to visit the city again in the coming years?; Would you recommend the city to others?

(iii) Spectator behaviour

9

(iv) Spectator opinion of local conditions

2

What is your opinion regarding:

If not, please answer the following statements:

Lenght of stay in the stadium

Reason to arrive early at the stadium

Transportation used

Visited this city only because of the game?

I watched the game because it coincided with my stay in the city; I extend my stay in the city to watch the game.

Stadium Accesses; Stadium capacity; Comfort of benches; Bathrooms and Animation at the Stadium

Restaurants; Attractions;

What is your opinion regarding the city of Paços de Ferreira:
Accommodation; Transport and Commerce

Source: made by the authors

answers: No (1) Improbable (2), I do not know (3) Probable (4) and Yes (5). In questions 19 and 20 the scale used was also with five points, and the possible answers were: Very Poor (1) Bad (2), I do not have (3) Good (4) and Very good (5). 
Five university students previously trained for this purpose applied the questionnaire to nonresidents spectators in the city of Paços de Ferreira in January 2016. To ensure the confidence of respondents was placed the logo of Faculty of Economics, University of Porto in the header and a brief introduction with the explanation of the purpose of the questionnaire and the guarantee of confidentiality in the use of data.

For data analysis a descriptive statistical were used to determine the mean, standard deviation, minimum and maximum values of the forty-two variables. In sixteen ordinal variables were calculated Cronbach alpha values and arrays of inter-item correlation and total-item to evaluate the internal consistency. All these statistical procedures were performed using SPSS (Statistical Package for Social Sciences) for Windows ${ }^{\circledR}$, version 22.0.

\section{CHARACTERIZATION OF THE CLUB}

The FCPF is a professional football club based in the city of Paços de Ferreira-Portugal, with more than 60 years of history. The club has participate in the main professional football league in Portugal for ten consecutive seasons. The club is recognized internationally, particularly in Portuguese-speaking African countries and in Europe for its participation in European competitions (Europa League (2007/08 and 2009/10) and Champions League (2013/14).

Data from the Portuguese Professional Football League (Liga Portuguesa de Futebol Professional), refers that, on the games played at home by the FCPF in 2014/2015, an average attendance is around about 2,900 spectators. However, in the games against the top three clubs of Portugal (Sport Lisboa e Benfica, Futebol Clube do Porto and Sporting Clube de Portugal), events can reach the maximum capacity of the stadium which is 6,452 spectators.

By conducting these events, the FCPF involves different types of football spectators as well as attenders, officials, media and other stakeholders in the organization and realization. In this context, this research is part of the type $\mathrm{D}$ events, i.e. a national character regular event, with many participants (professional athletes, technical teams, event organizers, media, etc.).

\section{RESULTS}

Results are presented according to the steps of statistical analysis performed using SPSS, namely: reliability and descriptive analysis. The analysis was performed separately because of the response options are dichotomous in some questions and polychotomous other.

In the dimension PE we found that the spectators were mostly male (93\%) and had an average age of 40 years, and $62.3 \%$ had between 25 and 54 years old. In terms of education, $60.5 \%$ had attended primary or secondary education and $39.7 \%$ higher education. 
The monthly income was mostly (70.7\%) below 1,500 euros. Regarding the area of residence, $72 \%$ came from the North of Portugal, and the majority was from the city of Porto. Respondents who travelled a greater distance travelled $399 \mathrm{~km}$ (Montemor-o-Novo).

In the dimension $\mathrm{CE}$ we found that $96.6 \%$ visited the city just because of the game. $51.7 \%$ of respondents had arrived less than ten minutes to the city at the time they were surveyed at the door of the stadium and $39.7 \%$ for more than $60 \mathrm{~min}$.

Regard to overnight in the city, only 3.4\% stayed overnight and they were installed in hotels. $37.9 \%$ of respondents intend to visit the city again in the coming years and only $50 \%$ would recommend the city to others. Finally, about $50 \%$ of respondents arrived at the stadium over ninety minutes before the start of the game, which shows that spectators are arrive early to the surroundings of the stadium.

In the dimension OE we note that the item 'access to the stadium' was considered by $60.3 \%$ of respondents as good. In the remaining items we denoted a lack of opinion (often through ignorance of the stadium and the city), as the option 'do not have' was always with the highest number of responses on all the others items.

The Table 2 shows the results of ordinal variables with respective number of items in each dimension.

In the dimension OE Cronbach alpha was 0.77; in the dimension $\mathrm{CE}$ was 0.61; and in the dimension PE was 0,38.

Table 3 shows the descriptive statistics (mean, standard deviation, maximum and minimum), asymmetry measures and flattening of the three dimensions.

In the case of OE dimension, the median values of the answers varied between 2 and 3 and the standard deviation ranged between 0.42 and 0.97 . In the case of CE dimension, the median values of the answers varied between 4 and 4.5 and the standard deviation ranged between 1.28 and 1.37. Finally, in the case of PE dimension, the median values were equal to 5 and the standard deviation ranged between 1.46 and 1.96 .

The Table 4 shows the Cronbach's alpha values and the relevance of each item on the respective dimension, and general reliability of the tool.

In the case of $\mathrm{OE}$ dimension, we can verify that when items OE_6 and OE_10 are removed from the instrument, the Cronbach's alpha varies from 0.77 to 0.78 . For the CE dimension, there is no change in Cronbach's alpha with the elimination of one of the items.

Table 2. Cronbach's alpha

\begin{tabular}{lccc}
\hline Dimension & Cronbach's alpha & $\begin{array}{c}\text { Cronbach's alpha based on } \\
\text { standard items }\end{array}$ & N. ${ }^{\text {o of itens }}$ \\
\hline Spectator opinion of local conditions (OE) & 0,773 & 0,790 & 10 \\
Spectator behaviour (CE) & 0,615 & 0,616 & 2 \\
Spectator profile (PE) & 0,380 & 0,406 & 4 \\
\hline
\end{tabular}

Source: made by the authors 
Table 3. Extent of response levels, means and flattening values and asymmetry

\begin{tabular}{|c|c|c|c|c|c|c|c|}
\hline & Mean & $\begin{array}{l}\text { Standard } \\
\text { Deviation }\end{array}$ & Variance & Asymmetry & Flattening & Min - Max & $\begin{array}{c}\mathrm{Z} \text { value } \\
\text { asymmetry }\end{array}$ \\
\hline $\begin{array}{l}\text { What is your opinion } \\
\text { regarding access to the } \\
\text { stadium (OE_1) }\end{array}$ & 3.48 & 0.84 & 0.71 & -0.76 & -0.58 & $2-5$ & -2.43 \\
\hline $\begin{array}{l}\text { What is your opinion } \\
\text { regarding the quality of } \\
\text { the stadium (OE_2) }\end{array}$ & 3.07 & 0.83 & 0.70 & 0.24 & -0.73 & $2-5$ & 0.77 \\
\hline $\begin{array}{l}\text { What is your opinion } \\
\text { about the comfort of } \\
\text { benches (OE_3) }\end{array}$ & 2.93 & 0.81 & 0.66 & 0.07 & 0.05 & $1-5$ & -0.23 \\
\hline $\begin{array}{l}\text { What is your opinion } \\
\text { regarding the bathrooms } \\
(\mathrm{OE} 4 \text { ) }\end{array}$ & 2.93 & 0.64 & 0.42 & -0.75 & 1.82 & $1-4$ & -2.39 \\
\hline $\begin{array}{l}\text { What is your opinion } \\
\text { regarding the animation in } \\
\text { the stadium (OE_5) }\end{array}$ & 3.28 & 0.97 & 0.94 & 0.25 & 0.18 & $1-5$ & 0.79 \\
\hline $\begin{array}{l}\text { What is your opinion } \\
\text { regarding the restaurants } \\
\text { (OE_6) }\end{array}$ & 3.52 & 0.75 & 0.57 & 0.57 & -0.31 & $2-5$ & 1.83 \\
\hline $\begin{array}{l}\text { What is your opinion } \\
\text { regarding the attractions } \\
\left(\mathrm{OE} \_7\right)\end{array}$ & 3.14 & 0.60 & 0.37 & 1.41 & 3.52 & $2-5$ & 4.49 \\
\hline $\begin{array}{l}\text { What is your opinion } \\
\text { regarding the } \\
\text { accommodations (OE_8) }\end{array}$ & 3.07 & 0.49 & 0.24 & 2.02 & 8.26 & $2-5$ & 6.44 \\
\hline $\begin{array}{l}\text { What is your opinion } \\
\text { in relation to transport } \\
\text { (OE_9) }\end{array}$ & 3.03 & 0.42 & 0.17 & 1.74 & 10.30 & $2-5$ & 5.55 \\
\hline $\begin{array}{l}\text { What is your opinion on } \\
\text { commerce (OE_10) }\end{array}$ & 3.45 & 0.73 & 0.53 & 1.03 & 0.11 & $2-5$ & 3.28 \\
\hline $\begin{array}{l}\text { Intend to visit the city } \\
\text { again in the coming } \\
\text { years? (CE_1) }\end{array}$ & 3.76 & 1.37 & 1.87 & -0.95 & -0.34 & $1-5$ & -3.03 \\
\hline $\begin{array}{l}\text { Would you recommend } \\
\text { the city to others? (CE_2) }\end{array}$ & 3.97 & 1.28 & 1.65 & -1.07 & 0.14 & $1-5$ & -3.40 \\
\hline $\begin{array}{l}\text { I practice/practiced } \\
\text { football (PE_1) }\end{array}$ & 4.38 & 1.46 & 2.13 & -1.96 & 1.90 & $1-5$ & -6.23 \\
\hline $\begin{array}{l}\text { I practice/practiced other } \\
\text { sports (PE_2) }\end{array}$ & 3.48 & 1.96 & 3.83 & -0.51 & -1.80 & $1-5$ & -1.63 \\
\hline $\begin{array}{l}\text { I follow football games of } \\
\text { lower leagues to the Liga } \\
\text { NOS (PE_3) }\end{array}$ & 3.83 & 1.837 & 3.37 & -0.93 & -1.17 & $1-5$ & -2.98 \\
\hline $\begin{array}{l}\text { I follow football matches } \\
\text { from international leagues } \\
\text { (PE_4) }\end{array}$ & 4.24 & 1.582 & 2.50 & -1.63 & 0.66 & $1-5$ & -5.18 \\
\hline
\end{tabular}

Source: made by the authors 
Table 4. Cronbach's alpha if item is excluded

\begin{tabular}{lc}
\hline Item & Cronbach's Alfa if item is excluded \\
\hline What is your opinion regarding access to the stadium (OE_1) & 0.742 \\
What is your opinion regarding the quality of the stadium (OE_2) & 0.751 \\
What is your opinion about the comfort of benches (OE_3) & 0.730 \\
What is your opinion regarding the bathrooms (OE_4) & 0.752 \\
What is your opinion regarding the animation in the stadium (OE_5) & 0.741 \\
What is your opinion regarding the restaurants (OE_6) & 0.780 \\
What is your opinion regarding the attractions (OE_7) & 0.744 \\
What is your opinion regarding the accommodations (OE_8) & 0.751 \\
What is your opinion in relation to transport (OE_9) & 0.755 \\
What is your opinion on commerce (OE_10) & 0.782 \\
Intend to visit the city again in the coming years? (CE_1) & 0.615 \\
Would you recommend the city to others? (CE_2) & 0.615 \\
I practice/practiced football (PE_1) & 0.344 \\
I practice/practiced other sports (PE_2) & 0.514 \\
I follow football games of lower leagues to the Liga NOS (PE_3) & 0.296 \\
I follow football matches from international leagues (PE_4) & 0.044
\end{tabular}

Source: made by the authors

At last, in the case of the PE dimension, we can observe that the item (PE_2) is damaging the instrument, so, if this item were removed from the dimension PE the Cronbach's alpha will improve to 0.51 .

Table 5 shows the inter-item correlation matrix of dimension PE.

As we mentioned before, the fact that the item (PE_2) be harming the instrument can be analysed through this matrix. We can observe that the item (PE_2) has a negative correlation with (PE_1 and PE_3), -0.041 and -0.035 , respectively. However, the results of this study showed

Table 5. Inter-item correlation matrix of dimension PE.

\begin{tabular}{lcccc}
\hline & $\begin{array}{c}\text { I practice/ } \\
\text { practiced football } \\
\text { (PE_1) }\end{array}$ & $\begin{array}{c}\text { I practice/ } \\
\text { practiced other } \\
\text { sports (PE_2) }\end{array}$ & $\begin{array}{c}\text { I follow football } \\
\text { games of lower } \\
\text { leagues to the } \\
\text { Liga NOS (PE_3) }\end{array}$ & $\begin{array}{c}\text { I follow football } \\
\text { matches from } \\
\text { international leagues } \\
\text { (PE_4) }\end{array}$ \\
\hline $\begin{array}{l}\text { I practice/practiced football } \\
\text { (PE_1) }\end{array}$ & 1,000 &,- 041 &, 142 &, 279 \\
\hline $\begin{array}{l}\text { I practice/practiced other } \\
\text { sports (PE_2) }\end{array}$ & 1,000 &,- 035 &, 166 \\
\hline $\begin{array}{l}\text { I follow football games of } \\
\text { lower leagues to the Liga NOS } \\
\text { (PE_3) }\end{array}$ & & 1,000 &, 365 \\
\hline $\begin{array}{l}\text { I follow football matches from } \\
\text { international leagues (PE_4) }\end{array}$ & & & 1,000 \\
\hline Source: made by the authors & & & \\
\hline
\end{tabular}


appropriate values for internal consistency and for the questionnaire adjustment indices in the context in which it was proposed.

In Table 6 are presented the average expenditure in various sections. Regarding expenditures on this sporting event we can observe that non-resident spectators spent an average of 18,95 euros in "Food and Drink"; 23,90 euros in "Travel Costs" and 20,41 euros in "Ticket to the game."

In the case of the consumption patterns of respondents' spectators (SC), we can see that 58 respondents brought an increase of 'new money' about 4,000 euros.

According to the data collected through the Futebol Clube Paços de Ferreira (FCPF), the number of spectators of this game was 5,920. It was also possible to verify that, with the items (tickets, bars in the stadium and club shop) this sporting event brought an increase of 'new money' of about 44,600 euros.

\section{DISCUSSION}

Regarding to non-resident spectator profile, there is a preponderance of males with a percentage of $93 \%$. These results corroborate other studies that proves most spectators were men (DIXON et al., 2012). This evidence is also found in other sports such as golf and basketball are traditionally events where men mostly respond to assistance (CORREIA; ESTEVES, 2007) but also in extreme sports such as freestyle motocross (KO et al., 2008).

The low number of non-resident female spectators (7\%) demonstrates the need of cities and organizers clubs sporting events in designing marketing strategies to attract women to these events, as argued by Khale (2001), strategies marketing in and through sport should be targeted to attract groups and different social classes.

In general spectators have an average age of 40 , and $62.3 \%$ of respondents had between 25 and 54 years old, these evidences suggest that games include a number of characteristics that pleases people during the most active stages of their lives, keeping that interest for a long time, so it is important to attract spectators from young ages (BISCAIA et al., 2010).

Regarding the education level $39.7 \%$ of the surveyed have higher education, $39.7 \%$ have secondary education and $20.7 \%$ primary education. These results show relatively high levels of education in relation to the Portuguese average and are similar to other studies (DICK; TURNER, 2007).

Table 6. Average expenditure

\begin{tabular}{lccccc}
\hline & Food and Drink & Shopping & Accommodation & Travel costs & Ticket to the game \\
\hline Mean & $18,95 €$ & $3,62 €$ & $1,72 €$ & $23,90 €$ & $20,41 €$ \\
Minimum & $0 €$ & $0 €$ & $0 €$ & $0 €$ & $0 €$ \\
Maximum & $100 €$ & $150 €$ & $50 €$ & $120 €$ & $100 €$ \\
\hline
\end{tabular}

Source: made by the authors 
Analysing the performance of surveyed, it shows that $70.7 \%$ of respondents have an average monthly income below 1500 euros standing in the second rank with annual incomes between 7035 20000 euros according to the IRS table for $2016^{1}$.

In terms of distance travelled 72\% came from nearby towns (e.g. Porto, Braga, Guimarães and Maia) and $28 \%$ of more distant cities (e.g. Lisboa) which represents a relatively large geographic dispersion. Pan (1997) state that spectators took between 30 and 60 minutes to reach the location of the game. In this sense, time is an important factor that must be observed by the organizers as it is crucial in creating promotional strategies.

In the dimension $\mathrm{CE}$ we found that $96.6 \%$ of respondents visited the city just because of the game which reveals the sense of belonging to the team thus highlighting the importance of social recognition and identification with the team. In relation to staying overnight in the city, only $3.4 \%$ overnight and were installed in hotels. $37.9 \%$ of respondents intend to visit the city again in the coming years and only $50 \%$ would recommend the city to others. Finally, about $50 \%$ of respondents arrived at the stadium over ninety minutes before the start of the game, which shows that spectators are arrive early to the surroundings of the stadium. Similar results are found by Preuss, Seguin and O’Reilly (2007).

The validation of the results of applied questionnaires was done through a factorial analysis, using Cronbach's alpha to assess the internal consistency. Was measured sensitivity range based on flattening and kurtosis coefficients.

In the Table 2 we can observe that Cronbach's alpha values obtained in the OE dimension are high and corroborate those recommended by the literature (CRONBACH, 1951; NUNNALLY, 1994; MARÔCO, 2014), since the values considered acceptable for instruments of this nature are above 0.70 .

For the other two dimensions, the Cronbach's alpha did not reach acceptable values. However, in the dimension (CE), the goal was to analyse the spectator intention regarding a future visit and the recommendation of the city, which means that the inconsistency may be related to the fact that, for example, a respondent would recommend city to others but not be considering visiting it in the near future.

In the case of PE dimension, we found that the response options did not fit with the statements. For example, to the statement 'I practice/practiced football' response options could not be in a Likert scale with options from 'Disagree' to 'Agree', but of 'Never' to 'Always' because in this way we can analyse whether the respondent practice or not practiced football, etc.

Through the analysis of Table 3 we can see that the answers to items OE_1, OE_4, OE_7, OE_8, OE_9 and OE_10 do not have a normal distribution, since the standard value ( $\mathrm{Z}$ value)

\footnotetext{
${ }^{1}$ Portal das Finanças: https://www.portaldasfinancas.gov.pt
} 
of asymmetry measures are outside the range considered normal (between -1.96 and 1.96) for a confidence interval of 95\% (PIRES et al., 2010).

The items OE_1 and OE_4 have a negative skewness (Figures 1 and 2) while the remaining items (OE_7, OE_8, and OE_9 OE_10) have a positive skewness (Figures 3, 4, 5 and 6). According to Marôco (2014), this means that in the first case, the bias to the right shows a predominance of higher values of the variable, revealing that the participants have a tendency to value these items questionnaire. On the other hand, in the second case, the bias on the left shows a predominance of the lower variable values, revealing that the participants have a tendency to downgrade the questionnaire items.

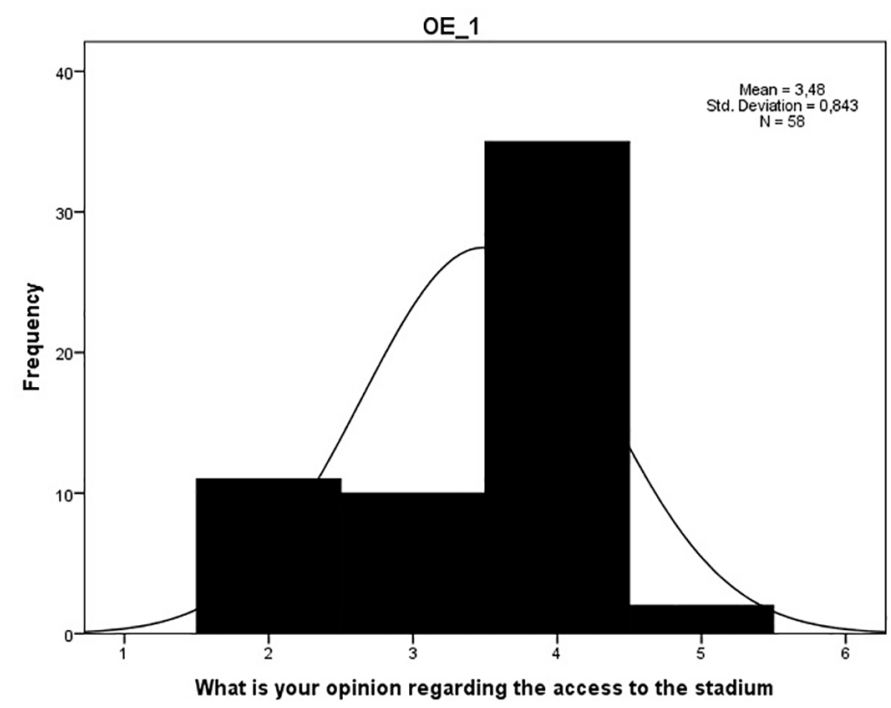

Figure 1. Source: Made by the authors in SPSS

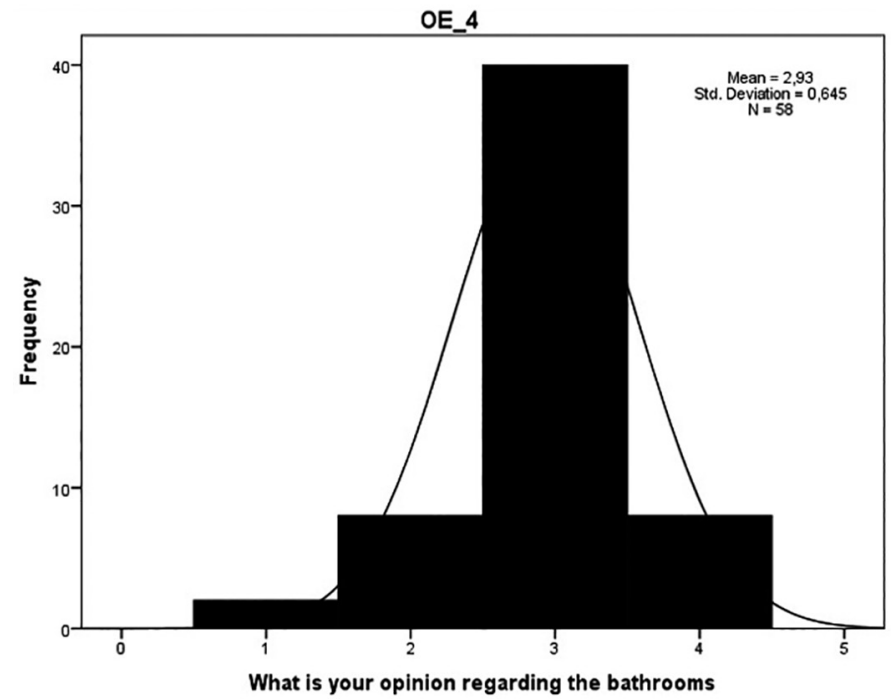

Figure 2. Source: Made by the authors in SPSS 


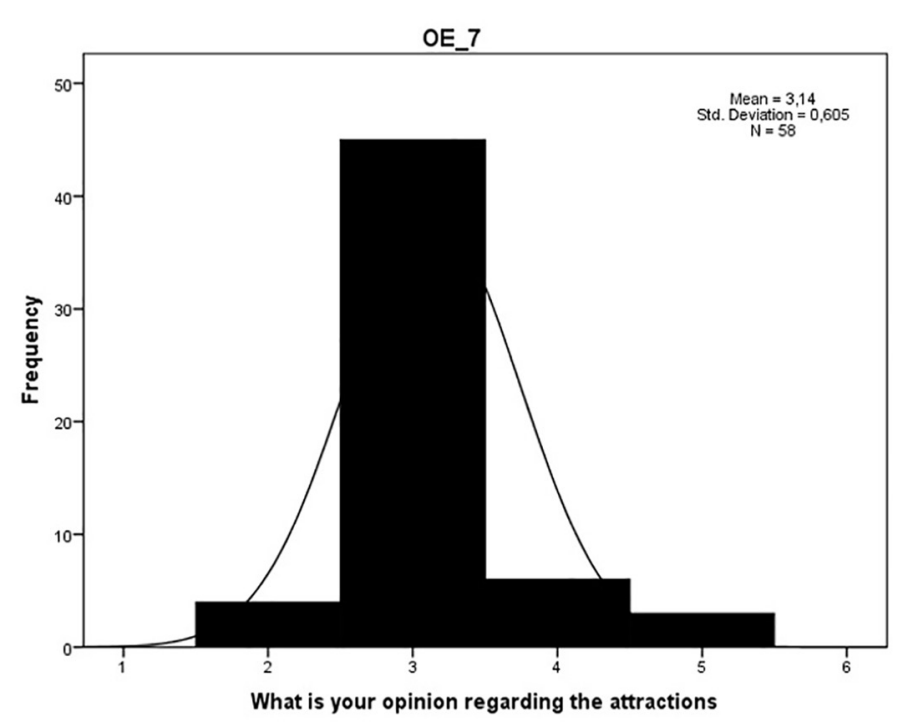

Figure 3. Source: Made by the authors in SPSS

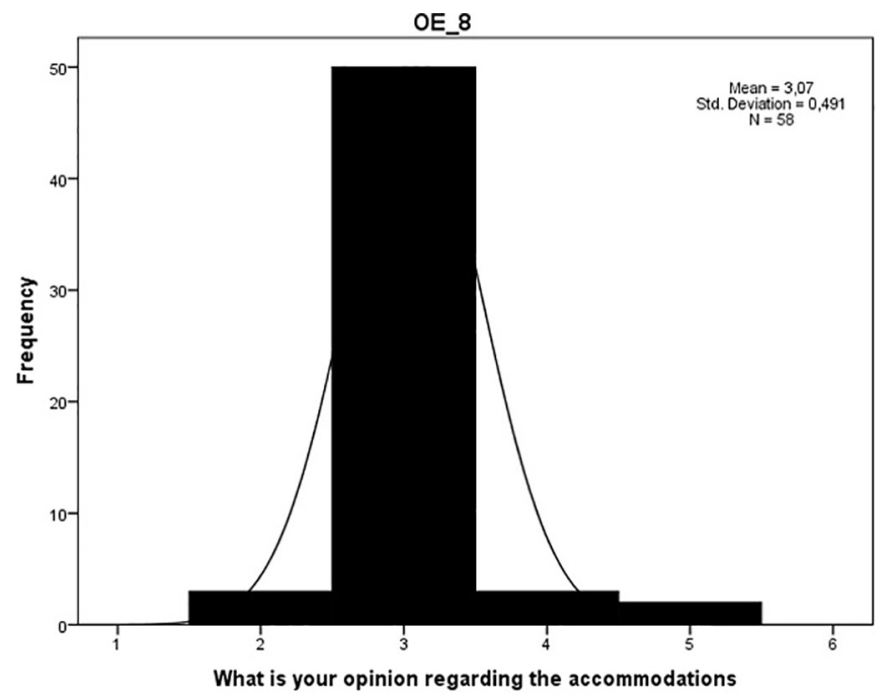

Figure 4. Source: Made by the authors in SPSS

Regarding the normal distribution we can observe that the two items of the dimension CE are outside of the confidence interval in the above mentioned size and have a negative skewness, that is, biased to the right with predominance of higher values of the variable (MARÔCO, 2014). About the normal distribution we note that the PE_1 items, PE_3 and PE_ 4 are outside the confidence interval mentioned in the previous dimensions and have a negative asymmetry, i.e., biased to the right with a predominance of the highest values of the variable (MARÔCO, 2014).

In Table 4 despite the fact that Cronbach alpha from dimension OE improve when items OE_6 and $\mathrm{OE} \_10$ are removed from the instrument, the increase is not very significant and therefore does not justify the elimination of items (BARROS et al., 2008). In relation to the Cronbach alpha from dimension PE the explanation will be given below by Table 5 analysis. 


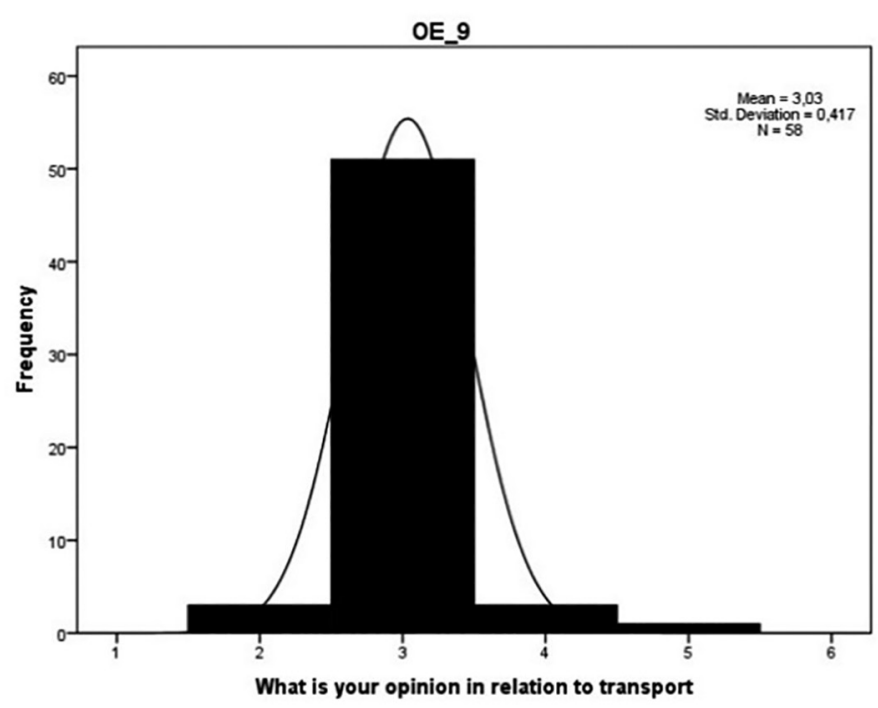

Figure 5. Source: Made by the authors in SPSS

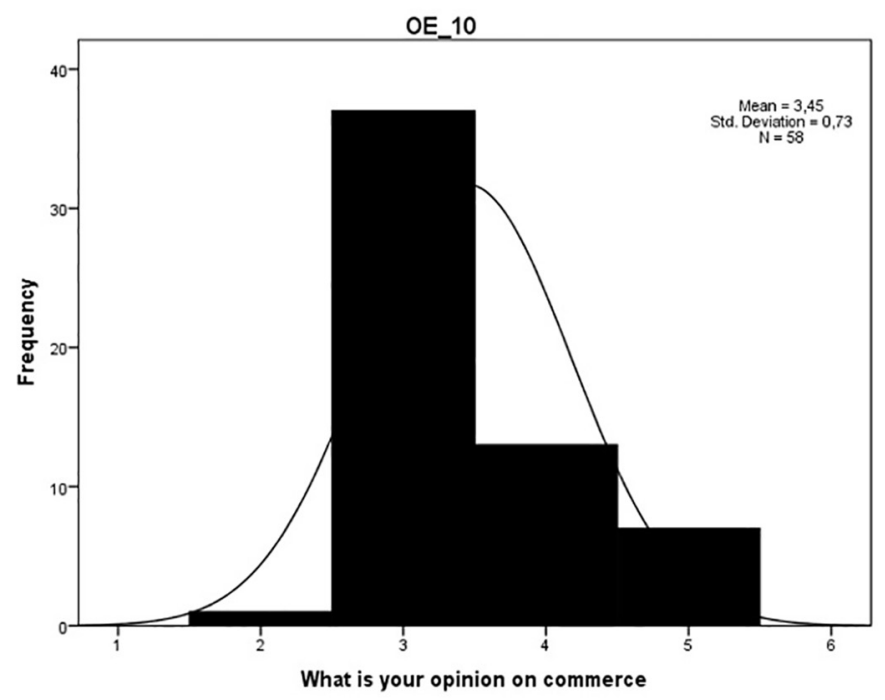

Figure 6. Source: Made by the authors in SPSS

In relation to Table 5 the negative correlation of item PE_2 with items PE_1 and PE_3 means that there is no correlation between practicing football and other sports; and practice other sports and follow up the football leagues below the Liga NOS. However, we believe that this question is important because the instrument checks the spectators of the events practice or no other sports.

In Table 6 we can see the average spending by non-residents spectators during the sporting event. As expected through the analysis of other studies (DAVIES, 2002) the items "Food and Drink" and "Ticket to the game" were those who achieved higher levels of spending. It was also expected that the items "Shopping" and "Accommodation" had lower values, that because the city of Paços de Ferreira is a city near the main communication axes of the country and the country abroad and only has 5 hotels and 2 centres commercial small. 
In short, the aim of this study was to adapt the research tool used by Preuss, Seguin and O'Reilly (2007) to the Portuguese reality, as well as verification of its psychometric properties. Statistical analysis on the sixteen ordinal variables of the instrument showed acceptable values with Cronbach's alpha values obtained are consistent with the recommendations from literature (MARÔCO, 2014). Thus, after the small change suggested above, we can state that the questionnaire is a good tool to analyse the consumption patterns of non-resident spectators at Liga NOS.

\section{CONCLUSIONS}

Taking into account the aim of this study, we can conclude that their initial psychometric properties prove the adequacy of adaptation performed, demonstrating that its structure has acceptable levels of validity and reliability.

Thus, it seems plausible to say that this tool is essential for the clubs and for the host cities of football games at Liga NOS, as it allows identifying the profile and consumption patterns of non-residents spectators who attend events, which will help to define marketing strategies more effective and efficient for clubs and host cities.

In terms of marketing strategy, the knowledge about the profile of non-resident spectator allows to match consumer demand with fair offers in terms of prices of products and services that can increase the notoriety of the clubs and cities.

This instrument is an important component to the knowledge of stakeholders in order to develop strategies that enhance the economic impacts in the short term, as well as extend the longterm benefits.

In general we can conclude that by the evidence of this research, soccer occupies a privileged position in the Portuguese society, so, in the context of marketing strategies is essential to communicate the games differently, depending on the characteristics of the spectators in order to increase affluence in stadiums, promoting the uptake of financial resources since by knowing the soccer target audience is more appealing to potential future sponsors.

However, it is important to note that future studies in the context of consumption patterns from spectators of sporting events in other cultures and other samples may have the need to adapt this instrument to local characteristics.

Despite the instrument has demonstrated good reliability indexes without changing its psychometric properties, in future studies is necessary to involve more non-resident spectators as well as to apply the questionnaire in several league matches.

\section{REFERENCES}

AGHA, N. The Economic Impact of Stadiums and Teams: The Case of Minor League Baseball. Journal of Sports Economics, v. 14, n. 3, p. 227-252, 2013. 
ALLAN, G.; DUNLOP, S.; SWALES, K. The Economic Impact of Old Firm Football Spectators as Sports Tourists: An Input-Output Application to Glasgow and Scotland. Journal of Sport \& Tourism, v. 12, n. 3, p. 63-97, 2007.

ALLEN, J. Organização e Gestão de Eventos. Rio de Janeiro: Editora Campus, 2007.

AMY, S. Spectator Profiles and Economic Impact of the 2009 US Women's Open. Thunderbird International Business Review, v. 49, n. 5, p. 630-631, 2007.

BAADE, R.; BAUMANN, R. W.; MATHESON, V. Assessing the Economic Impact of College Football Games on Local Economies. Journal of Sports Economics, v. 9, n. 6, p. 628-643, 2008.

BARAJAS, A.; COATES, D.; SANCHEZ-FERNANDEZ, P. Beyond retrospective assessment sport event economic impact studies as a management tool for informing event organization. Investigaciones Europeas de Dirección Y Economía de La Empresa, p. 1-7, 2015.

BARREAU, G. Gestão do Risco na Organização de Eventos Desportivos. Seminário Internacional de Gestão de Eventos Desportivos. Lisboa, 2001.

BARROS, M.; REIS, R.; FLORINDO, A.; HALLAL, P. Análise de dados em saúde. Recife: EDUPE, 2005.

BISCAIA, R.; CORREIA, A.; ROSADO, A.: Sociodemographic profile and motives of basketball spectatores. Revista Brasileira de Ciências do Esporte, v. 32, n. 2-4, p. 199-216, 2010.

CHURCHILL, G. Marketing: Criando Valor Para Os Clientes. São Paulo: Saraiva, 2005.

CORREIA, A.; ESTEVES, S.: An exploratory study of spectator's motivation in football. International Journal of Sport Management and Marketing. v. 2, n. 5-6, p. 572-590, 2007.

CROMPTON, J. L. Economic Impact Analysis of Sport Facilities and Events: eleven sources of misapplication. Journal of Sport Management, v. 9, n. 1, p. 14-35, 1995.

CROMPTON, J. L. Economic Impact Studies: Instruments for Political Shenanigans? Journal of Travel Research, v. 45, n. 1, p. 67-82, 2006.

CROMPTON, J. L.; LEE, S.; SHUSTER T. J. A Guide for Undertaking Economic Impact Studies: The Springfest Example. Journal of Travel Research, v. 40, n. 1, p. 79-87, 2001.

CRONBACH, L. J. Coefficient alpha and the internal structure of tests. Psychometrika, v. 16, n. 3, p. 297-334, 1951

DAVIES, L. E. Consumers' expenditure on sport in the UK: increased spending or underestimation? Managing Leisure, v. 7, p. 83-102, 2002

DICK, R.; TURNER, B. Are fans and NBA marketing directors on the same page? A comparison of value of marketing techniques. Sport Marketing Quarterly, v. 16, n. 3, p.140-146, 2007.

DIXON, A.; BACKMAN, S.; BACKMAN, K; NORMAN, W.: Expenditure-based segmentation of sport tourists. Journal of Sport \& Tourism, v. 17, p. 5-21, 2012.

GETZ, D. Event tourism: Definition, evolution, and research. Tourism Management, v. 29, p. 403-428, 2008.

GIBSON, H. J.; KAPLANIDOU, K.; KANG, S. J. Small-scale event sport tourism: A case study in sustainable tourism. Sport Management Review, v. 15, n. 2, p. 160-170, 2012. 
GIBSON, H.; MCINTYRE, S.; MACKAY, S.; RIDDINGTON, G. The Economic Impact of Sports, Sporting Events, and Sports Tourism in the U.K. The DREAM ${ }^{\mathrm{TM}}$ Model. European Sport Management Quarterly, v. 5, n. 3, p. 321-332, 2005.

GOLDBLATT, J. A future for event management: the analysis of major trends impacting the emergening profession. Events beyond 2000: setting the agenda, p. 2-9, 2000.

GÓMEZ-BANTEL, A. Football clubs as symbols of regional identities. Soccer \& Society, p. 1-11, 2015.

GRATTON, C. The economic impact of sport tourism at major events. Oxford: Elsevier ButterworthHeinemann, 2005.

GRATTON, C.; DOBSON, N.; SHIBLI, S. The economic importance of major sports events: a case-study of six events. Managing Leisure, v. 5, n. 1, p. 17-28, 2000.

GRATTON, C.; SHIBLI, S.; COLEMAN, R. The economic impact of major sports events: A review of ten events in the UK. Sociological Review, v. 54, n. 2, p. 41-58, 2006.

GUTTMAN, A. Sports Spectators. New York: Columbia University Press, 1986

HALL, C. Hallmark Tourist Events: Impacts, Management, and Planning. London: Belhaven, 1992.

HASSAN, D.; CONNOR, S. O. The socio-economic impact of the FIA World Rally Championship 2007. Sport in Society, v. 12, n. 6, p. 709-724, 2009.

HINCH, T. D.; HIGHAM, J. E. S. Sport tourism: A framework for research. International Journal of Tourism Research, v. 3, n. 1, p. 45-58, 2001.

HUANG, H.; MAO, L. L.; KIM, S. K.; ZHANG, J. J. Assessing the economic impact of three major sport events in China: the perspective of attendees. Tourism Economics, v. 20, n. 6, p. 1277-1296, 2014.

KHALE, L.: The social values of fans for men's versus women's university basketball. Sport Marketing Quarterly, v. 10, n. 2, p. 156-162, 2001.

KO, Y. J.; PARK, H.; CLAUSSEN, C. L. Action sports participation: consumer motivation. International Journal of Sports Marketing and Sponsorship, v. 9, n. 2, p. 111-124, 2008.

KOTLER, P. Administração de Marketing. São Paulo: Pearson Education, 2012.

LAMLA, M. J.; STRAUB, M.; GIRSBERGER, E. M. On the Economic Impact of International Sport Events: Microevidence from Survey Data at the EURO 2008. Applied Economics, v. 46, n. 13, p. 1693-1703, 2014.

LERA-LÓPEZ, F.; OLLO-LÓPEZ, A.; RAPÚN-GÁRATE, M. Sports spectatorship in Spain: Attendance and consumption. European Sport Management Quarterly, v. 12, n. 3, p. 265-289, 2012.

MAK, J. Tourism and the Economy: Understanding the Economics of Tourism. Hawaii: University of Hawaii Press, 2004.

MARÔCO, J. Análise Estatística com o SPSS Statistics. Lisboa: ReportNumber, 2014.

MONDELlO, M. J. Comparative Economic Impact Analyses: Differences Across Cities, Events, and Demographics: A Reply. Economic Development Quarterly, v. 20, n. 2, p. 196197, 2006. 
MULES, T.; DWYER, L. Public Sector Support for Sport Tourism Events: The Role of Costbenefit Analysis. Sport in Society, v. 8, n. 2, p. 338-355, 2005.

NUNNALLY, J. Psychometric Theory. New York: McGraw-Hill, 1994.

PAN, D. W.: Factors and differential effects on purchases of season tickets for intercollegiate basketball games. Journal of Sport Behavior, v. 20, n. 4, p. 125-142, 1997.

PIRES, A.; CID, L.; BORREGO, C.; ALVES, J.; SILVA, C. Validação preliminar de um questionário para avaliar as necessidades psicológicas básicas em Educação Física. Revista Motricidade, v. 6, n. 1, p. 33-51, 2010.

PREUSS, H. Calculating the regional economic impact of the olympic games. European Sport Management Quarterly, v. 4, n. 4, p. 234-253, 2004.

PREUSS, H. The Economic Impact of Visitors at Major Multi-sport Events. European Sport Management Quarterly, v. 5, n. 3, p. 281-301, 2005.

PREUSS, H.; SEGUIN, B.; O'REILLY, N. Profiling Major Sport Event Visitors: The 2002 Commonwealth Games. Journal of Sport \& Tourism, v. 12, n. 1, p. 5-23, 2007.

RATTEN, V. The dynamics of sport marketing: Suggestions for marketing intelligence and planning. Marketing Intelligence \& Planning, v. 34, n. 2, p. 162-168, 2016.

RATTEN, V.; RATTEN, H. International sport marketing: practical and future research implications. Journal of Business \& Industrial Marketing, v. 26, n. 8, p. 614-620, 2011.

SANDY, R. The economics of sport: an international perspective. New York: Palgrave Macmillan, 2004.

SANTOS, J. M. S.; GARCIA, P. C. A Bibliometric Analysis of Sport Economics Research. International Journal of Sport Finance, v. 6, n. 3, p. 222-244, 2011.

SANZ, V. A.; MORENO, F. C.; CAMACHO, D. P. Impacto social de un gran evento deportivo: El Gran Premio de Europa de Fórmula 1. Cultura, Ciencia Y Deporte, v. 7, p. 53-65, 2012.

SARMENTO, J. P.; PINTO, A. DA SILVA, C.; PEDROSO, C. O Evento Desportivo: Etapas, Fase e Operações. Revista Intercontinental de Gestão Desportiva, v. 1, n. 2, 2011.

SIEGFRIED, J.; ZIMBALIST, A. The economic impact of sports facilities, teams and mega-events. Australian Economic Review, v. 39, n. 4, p. 420-427, 2006.

TRAIL, G. T.; FINK, J. S.; ANDERSON, D. F. Sport spectator consumption behavior. Sport Marketing Quarterly, v. 12, n. 1, p. 8-10, 2003.

WILSON, R. The economic impact of local sport events: significant, limited or otherwise? A case study of four swimming events. Managing Leisure, v. 11, n. 1, p. 57-70, 2006.

WILTON, J. J. Collecting and Using Visitor Spending Data. Journal of Travel Research, v. 45, p. $17-25,2006$. 